\title{
ПОЕТИЧНІ СПОГАДИ, ПРИСВЯЧЕНІ ЛІТЕРАТУ РНІЙ ДІЯЛЬНОСТІ АЛОЇЗА ФЕЛІНСЬКОГО (НА ПРИКЛАДІ ВІРШІВ, ОПУБЛІКОВАНИХ У ПРЕСІ ХІХ СТ.)
}

\author{
Магдалена Патро-Куцаб \\ Інститут польської філологї Жешувського університету \\ просп. Рейтана, 16в, 35-959 Жешув, Польща \\ e-mail:mpatro@ur.edu.pl
}

У статті представлено авторський аналіз і інтерпретацію творів Гжегожа Ігнація Шадбея під назвою Elegia na śmierć Alojzego Felińskiego (Елегія для смерті Алозія Фелінського), опублікованого 25 квітня 1820 року в «Rozmaitości» (додаток до «Газета Lwowska») і Вінсента Турського - Do cieniów Alojzego Felinskiego (До тіней Алозія Фелінського), опублікованого в «Weteran Poznański» в лютому 1825 року.

Інтерпретація спрямована не тільки на формування портрету Фелінського, який був створений поетами, зазначеними вище, але перш за все це спроба представити вищезгадані вірші в пресі в конвенції мемуарів.

Автор хоче довести, що вірші Шадбея і Турського носять інформативний характер з одного боку (вони приносять знання про професійну діяльність Фелінського), але вони також містять елементи оцінки - вони представляють автора Барбари Радзивилівни як прекрасного поета і шляхетну людину.

Ключові слова: спогади і портрети Алозія Фелінського, преса, газетний текст, благородна модель.

23 lutego 1820 roku w Krzemieńcu zmarł nagle Alojzy Feliński. Dzień wcześniej uczestniczył «w proszonym obiedzie» $\mathrm{i}$ - jak wspomina w swej mowie Jan Sowiński «jeszcze kilka godzin przed swym zgonem, z wrodzoną sobie dobrocią, uprzejmością i wesołością umilał towarzystwo nasze, jeszcze się był zatrudniał dobroczynną na nieszczęśliwych składką, która mu powierzona została [...]» [Sowiński 1820: 330]. Po powrocie do domu poświęcił około godziny na rozmowę z synem. Następnie wydał dyspozycje służącemu i, wyczerpany obowiązkami i przyjemnościami mijającego dnia, zasnął. Klemens Kantecki w pracy poświęconej krzemienieckiemu profesorowi zdradza okoliczności jego śmierci:

[...] spoczął - w rzeczy samej - lecz snem wiecznym. Nazajutrz służący, stosując się do rozkazu, omijał starannie pańską sypialnię. Przed ósmą, jak zwykle, kilka osób przyszło z interesami; zdziwili się oni, słysząc, że tak pilny dyrektor jeszcze zasypia. Postanowili czekać, lecz gdy godziny upływały, a w sypialni nic nie przerywało głuchej ciszy, jeden z uczniów uchyliwszy drzwi, przekonał się, że w łóżku leżą martwe zwłoki ... Feliński umarł na apopleksję. Wiadomość o smutnym wypadku rozbiegła się po mieście z szybkością iskry elektrycznej, Krzemieniec i Wołyń cały ciężko odczuły tę stratę, która w innych dzielnicach kraju wywołała żal powszechny. Pogrzeb mu sprawiono wspaniały [Kantecki 1879: 153].

Nagły zgon dyrektora krzemienieckiego Liceum upamiętniły liczne mowy (np. Alojzego Osińskiego, Jana Sowińskiego, Jana Tarnowskiego czy Michała Wyszkow-

(C) Патро-Куцаб М., 2014 
skiego) oraz wiersze (m. in. Konstantego Piotrowskiego, Grzegorza Ignacego Szadbeya czy Tymona Zaborowskiego) $)^{1}$. Jednak do dziś w większości nie doczekały się one szerszych omówień krytycznych czy historycznoliterackich.

W egzemplifikacji sięgam po dwa wiersze. Pierwszy, autorstwa Grzegorza Ignacego Szadbeya ${ }^{2}$ pt. Elegia na śmierć Alojzego Felińskiego [Szadbey 1820: 185], opublikowany 25 kwietnia 1820 roku w «Rozmaitościach» (dodatku do «Gazety Lwowskiej»); drugi nosi tytuł Do cieniów Alojzego Felińskiego [Turski 1825: 57-61] i wyszedł spod pióra Wincentego Turskiego, a został wydrukowany w «Weteranie Poznańskim» w lutym 1825 roku.

Obaj autorzy poświęcają swe utwory Alojzemu Felińskiemu i ogłaszają je w ówczesnej prasie. Nieprzypadkowy jest również czas publikacji, Elegię ... ogłoszono w dwa miesiące po śmierci autora Barbary Radziwitłówny, zaś Do cieniów ... - w piątą rocznicę śmierci wołyńskiego poety. Każdy z autorów wspomina Felińskiego jako człowieka i artystę, którego odejście stało się niepowetowaną stratą nie tylko dla społeczeństwa Wołynia, ale i dla całego polskiego narodu. A zatem obaj twórcy piszą swoistego rodzaju wspomnienie, które jest obrazem osoby. Tym samym stają się autorami portretu gospodarza Osowy.

Celem niniejszej pracy będzie zatem próba zaprezentowania wspomnianych powyżej wierszy jako swoistego rodzaju sylwetek-wspomnień, gatunku chętnie wykorzystywanego w prasie w celu upamiętnienia znaczącej osoby. Specyfika czy raczej ich pewna nietypowość przejawia się przede wszystkim w sposobie zapisu «portretów» - w mowie wiązanej. Jednak należy pamiętać, że prezentowane tu sylwetki dotyczą osoby zmarłej, zatem ich kształt artystyczny nawiązuje do elegii i jest rodzajem lamentu po jej śmierci, a przecież za przynależną temu gatunkowi uważa się formę wierszową [Danielewicz 1984: LX].

Przypomnijmy, że występujący w prasie gatunek o nazwie «sylwetka» czy «portret» zasadniczo pełni charakter informacyjny, jednak nie jest pozbawiony elementów wartościowania $^{3}$ [Por. Wojtak 2004: 120]. Podobnie było w wieku XIX, kiedy określenia te oznaczały kolejno: 'obraz wyrażający osobę' [Linde 1811: 929, hasło: portret] oraz 'wspominać, spominać [...] kogo, wzmiankę czynić' [Linde 1814: 328-329, hasło: wspominacz]. Wspomniana powyżej Maria Wojtak wykazała, że «analizy bogatego zbioru wypowiedzi pozwalają postrzegać »sylwetkę« jako genologiczną osobliwość $\mathrm{z}$ tego powodu, że nie zdołała zastygnąć w jednej formie», dalej zaś dodaje, iż «prezentacja osoby może też być rozłożona na kilka komunikatów o zróżnicowanej formie gatunkowej» [Wojtak 2004: 120]. Mając na uwadze fakt, że celem «portretu» jest pochwalenie określonego człowieka (wymiar pragmatyczny) oraz ukazanie charakterystyki konkretnej osoby (wymiar poznawczy) [Por. Wojtak 2004: 121], można spróbować spojrzeć na utwory Szadbeya i Turskiego jako swoistego rodzaju sylwetki-wspomnienia, których autorzy nie tylko opłakują, ale przede wszystkim prezentują postać niedawno zmarłego poety.

Wyjaśnienia wymaga jeszcze jedna kwestia - czy osobę wspominającą zmarłego powinna łączyć z nim jakaś szczególna więź? Jak podkreśla Wojtak nie jest to warunek konieczny, można bowiem pisać o określonym człowieku na podstawie różnorodnych źródeł [Por. Wojtak 2004: 123]. W przypadku wskazanych przeze mnie wierszy

\footnotetext{
${ }^{1}$ Por. też na ten temat uwagi Andrzeja K. Guzka [Guzek 2004: 210] oraz Magdaleny Patro-Kucab [Patro-Kucab 2013: 119].

${ }^{2}$ Formę nazwiska oraz jego zapis podaję za Elżbietą Aleksandrowską z zespołem [Aleksandrowska z zesp., oprac. 1966: 455, hasło: Feliński Alojzy].

${ }^{3}$ Por. także na ten temat uwagi Marii Wojtak zamieszczone w przypisie 1 [Por. Wojtak 2004: 120].
} 
Felińskiego wspominają artystę poeci minorum gentium. Grzegorz Ignacy Szadbey był przede wszystkim adwokatem, urodzonym w roku 1796 w Tyśmienicy. Już jako nastolatek zdradzał poetycki talent, więc rodzina zdecydowała, że młodzieniec zdobędzie wykształcenie uniwersyteckie (studiował na uniwersytecie we Lwowie). Szadbey zadebiutował omawianą na kartach niniejszej rozprawy Elegia na śmierć Alojzego Felińskiego. Był to debiut w piśmie cieszącym się wówczas we Lwowie znaczną poczytnością, szczególnie przez płeć piękną. W tym samym numerze «Rozmaitości» wierszopis opublikował także utwór pt. Piękność [Szadbey 1820: 188]. Pisanie stanowiło dla niego rodzaj zajęcia dodatkowego, bowiem przede wszystkim był biegłym adwokatem specjalizującym się w prawie spadkowym [Por. Zięba 2014].

Z kolei Wincenty Turski urodził się w Brześciu Litewskim w 1772 roku, wykształcenie zdobył w Szkole Rycerskiej, służył w wojsku Wielkiego Księstwa Litewskiego, w roku 1794 podpisał akces do powstania, potem sprawował także funkcję urzędniczą w departamencie krakowskim, a następnie komendanta Korpusu Kadetów w Chełmnie. W roku 1815 przeniósł się do Poznania i tu w 1825 roku redagował i wydawał pismo pt. «Weteran Poznański». Ogłaszał w nim nie tylko własne próby poetyc$\mathrm{kie}^{4}$, ale przede wszystkim wiersze brata - Wojciecha [Por. Aleksandrowska z zesp., oprac. 1970: 375, hasło: Turski Wincenty].

Przypomnijmy, że klasyczna wersja wspomnienia rozpoczyna się tytułem, który jednocześnie jest informacją o śmierci wspominanej osoby. W przypadku omawianych tu wierszy «nagłówki» wyglądają następująco:

Elegia na śmierć Alojzego Felińskiego [Szadbey 1820: 185]

Do cieniów Alojzego Felińskiego [Turski 1825: 57].

W utworze Szadbeya otrzymujemy nie tylko powiadomienie o śmierci Felińskiego, ale także informacje o kwalifikacji gatunkowej, w jakiej utrzymane będzie wspomnienie. Biorąc pod uwagę fakt, że utwór był ogłoszony zaledwie dwa miesiące po śmierci krzemienieckiego profesora, jego autor zapewne zupełnie świadomie sięga po gatunek nawiązujący do formy lamentu czy żalu, bowiem - jak zauważył Roman Doktór, czyniąc swoje uwagi o elegii na marginesie poezji porozbiorowej - «poczucie straty [...] jest podstawowym atrybutem elegii funeralnej» [Doktór 1999: 187]. Tytuł w tym przypadku przynosi informację (o zgonie Felińskiego) oraz stanowi rodzaj komentarza do tego wydarzenia (należy wyrazić żal, ubolewanie po stracie poety).

Nieco inaczej jest w przypadku wspomnienia autorstwa Turskiego. Przypomnijmy, że upamiętniony w nim autor Barbary... nie żyje już od pięciu lat. Mamy zatem na uwadze utwór rocznicowy, w którym informacja na temat śmierci otrzymuje charakter metaforyczny («cienie Felińskiego» - możemy je tłumaczyć jako odniesienie do postaci, którą przybrał poeta po śmierci, ale też do duszy zmarłego, portretu osoby nieżyjącej; także spuścizny po artyście) [Por. Kopaliński 1991: 46-48, hasło: cień] ${ }^{5}$.

Przechodząc do zasadniczej części omawianych na kartach niniejszej pracy wierszy, należy na wstępie podkreślić, że w klasycznej wersji prasowego wspomnienia «pierwszy akapit informuje zwięźle o smutnym wydarzeniu, nie zawiera zatem nowej

\footnotetext{
${ }^{4}$ Przykłady innych wierszy Wincentego Turskiego ogłoszone na łamach «Weterana Poznańskiego»: Wiosna; Do Dyrektora Warszawskiego Liceum, «Weteran Poznański» 1825, nr 1, s. 1-10, 10-12; Na śmierć Xiażęcia Adama Czartoryskiego, Jenerała Ziem Podolskich, Kommendanta Korpusu Kadetów Warszawskich itd., «Weteran Poznański»1825, nr 2, s. 61-62.

${ }^{5}$ Na temat tytulatury wspomnień por. też uwagi Marii Wojtak [Por. Wojtak 2004:123-124].
} 
porcji informacji» [Wojtak 2004: 123]. Tak jest w zasadzie i w przypadku prezentowanych utworów:

Słuchaj szanowny Polski Helikonie!

Ty szumny Dniestrze, wy Wołynia błonie:

Spełzła nadzieja, radość się w żal zmienia;

Słuchajcie smutku i żałoby pienia [Szadbey 1820: 185].

Feliński! nie dość jeszcze syte zagład wrogi,

Przed czasem zmiotly Ciebie z kwiecistej prac drogi.

Lecz chciwszy w Tobie utrat obraz wyryć wierny,

Trza nadziei z nim zgasłych wskazać rys niezmierny [Turski 1825: 57].

Szadbey, informując o śmierci Felińskiego, jednocześnie zaprasza do wysłuchania lamentu nad jego zgonem wyznawców muz, a przede wszystkim lutni Apollina («Polski Helikon»), a także - zgodnie z konwencją elegii - naturę («szumny Dniestr» i «błonie Wołynia»), która także powinna ubolewać nad śmiercią wspaniałego męża.

W przypadku wspomnienia Turskiego, pisanego - na co już zwracano uwage - z pespektywy czasu, autor wiersza przekazuje wiadomość o śmierci Felińskiego (jednocześnie wpisując jego odejście w ciąg strat, jakie od drugiego dziesięciolecia XIX wieku prześladują polski naród - «niedość jeszcze syte zagład wrogi» ${ }^{6}$ ) i czuje potrzebę przypomnienia i upamiętnienia jego zasług - «trza nadziei z nim zgasłych wskazać rys niezmienny».

Obaj poeci w pierwszych strofach swych poetyckich wspomnień informują bądź przypominają o zgonie autora Barbary... oraz zachęcają do wysłuchania pośmiertnego czy rocznicowego żalu.

Jeśli wskazane wiersze będziemy rozpatrywać jako swoistego rodzaju sylwetki-wspomnienia zamieszczone $\mathrm{w}$ prasie, przechodząc do kolejnych strof powinniśmy natrafić na informacje na temat zmarłej osoby. Jak wykazuje Maria Wojtak współcześnie ta część może, ale nie musi być utrzymana w konwencji życiorysu (np. dane na temat miejsca i czasu urodzenia, zdobytego wykształcenia, przebiegu działalności zawodowej) $)^{7}$ [Por. Wojtak 2004: 123].

W części zasadniczej pamiątek o Felińskim obaj autorzy skupiają się przede wszystkim na jego dokonaniach w zakresie języka i literatury, a zatem omawiają działalność zawodową Wołynianina. Rozpoczynając od uwag nad językiem, należy podkreślić, że szczególnie dokładnie i dobitnie charakteryzuje te kwestie Turski, który pisze:

I to pisowni polskiej troskliwe śledzenie,

Przerwy swojej bolesne sprawia przepełnienie.

$[\ldots]$

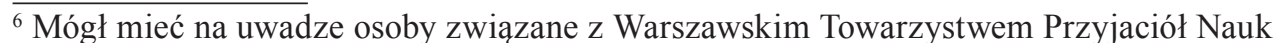
(np. Tadeusza Czackiego, zm. 1813 r.; Konstantego Tymienieckiego, zm. 1814 r.; Onufrego Kopczyńskiego, zm. 1817; Michała Dymitra Tadeusza Krajewskiego, zm. 1817 r.; Stanisława Kostkę Potockiego, zm. 1821 r.; Marcina Molskiego, zm. 1822 r.).

Por. też utwór Marcina Molskiego pt. Wiersz na zgon ś.p. Stanistawa Hrabi Potockiego, wojewody, prezesa senatu królestwa polskiego, w dniu 14 miesiąca września 1821 zmarlego: «W przeciaggu lat niewielu dzwonów głos ponury, / Odbijał się pięćkrotnie o stołeczne mury») [Molski 1821: 313-315].

${ }^{7}$ Zdaniem Wojtak wystarczy, by przynajmniej jeden akapit nawiązywał do konwencji biogramu [Por. Wojtak 2004: 126].
} 
Głośny wasz spór w pisowni, spór uczonych zdania,

Do ścisłego rozbioru niemało nakłania.

Któż te spory rozstrzygnie? rzecz samą ustali?

Śniadecki jeniuszem, co w probierskiej ${ }^{8}$ szali,

Zważywszy talent, zdolność, błędy, omamienia,

Na gwicht ${ }^{9}$ mądrości wartość wysileń ocenia.

A jak Jowisz Tytanów pogromcą się staje,

Tak Śniadecki wymową cios zguby zadaje;

Miota w niej grom za gromem na powstałe głowy,

Co śmią bluźnić majestat staropolskiej mowy.

Światłe pisma Śniadeckich klassyczne są dzieła;

Uczona mądrość wszystkie karty tam zajęła.

Lecz mniej słusznie krytyka przy jeziorze Gople,

Sączy na Felińskiego cierpkie nieco krople.

Czyż człowiek nieomylnie prawdę śledzić umie?

Najczęściej jej dochodzi w ciągłych błędów tłumie.

Dobrą jest ironia na krnąbrne narowy:

Feliński wzywał rady, przyjąć był gotowy [Turski 1825: 58].

Turski pisząc o zasługach Felińskiego na polu ortograficznej kodyfikacji, choć nie czyni tego bezpośrednio przez przywołanie tytułu pracy reformatora, to jednak wyraźnie odnosi się do rozprawy dramaturga pt. Przyczyny używanej przeze mnie pisowni (wyd. 1816 r.) $)^{10}$. Przypomnijmy, że w rolę kodyfikatora języka narodowego wcielił się gospodarz Osowy na krótko przed publikacją pierwszego tomu swoich dzieł zebranych, co potwierdza we wstępie do Przyczyn używanej [...] pisowni. [Feliński 1840: 105-106]. Argumentem przemawiającym za przeglądem pisowni, a następnie przygotowaniem (nie tylko na własny użytek) reformy ortografii w drugiej dekadzie XIX wieku, okazał się przede wszystkim - z jednej strony panujący w tym zakresie chaos, z drugiej zaś - nadzieja, że mimo istniejących przyzwyczajeń użytkowników polszczyzny, uda się usunąć występujące w naszej pisowni niektóre niekonsekwencje czy błędy. Feliński wyrażał przy tym wielki szacunek dla dotychczasowych reformatorów języka ojczystego [Feliński 1840: 107]. Poeta doceniał także osiągnięcia Onufrego Kopczyńskiego [Kopczyński 1778], mimo że nie wszystkie propozycje księdza pijara uznawał za trafne ${ }^{11}$ [Feliński 1840: 137-143], co w swym wierszu podkreśla także Turski. Myśląc o reformie języka Feliński miał na uwadze przejrzenie pisowni polskiej oraz próbę jej udoskonalenia, a wszelkie uchybienia w tym zakresie tłumaczył cudzoziemskim pochodzeniem naszych drukarzy, skłonnością Polaków do barbaryzmów oraz niechęcią do języka ojczystego. Do podobnych działań namawiał też innych pisarzy [Feliński 1840: 114]. Po ogłoszeniu Przyczyn używanej [...] pisowni roze-

\footnotetext{
8 'od probowania' [Linde 1811: 1038, hasło: probierny, probny, probierski].

9 'waga szalna' [Linde 1808: 810, hasło: gwicht].

${ }^{10} \mathrm{Na}$ temat wydań dzieł Alojzego Felińskiego zob. [Aleksandrowska z zesp., oprac. 1966: 451-455, hasło: Feliński Alojzy].

Szczegółowo utwór ten został omówiony w pracy Magdaleny Patro-Kucab [Patro-Kucab 2014: 101-111]. Na kartach niniejszej rozprawy przypominam jedynie niektóre kwestie dotyczące sporu, który przywołuje w swym wierszu Turski. Lakoniczne uwagi, przy okazji przeglądu reform polskiej ortografii, zgłaszali już wcześniej na ten temat Jan Łoś [Łoś 1917: 55-98] czy Stanisław Jodłowski [Jodłowski 1979: 81-82], a także - omawiając zainteresowania językoznawcze Jana Śniadeckiego - uczynił to Zdzisław Libera [Libera 1994: 355-364].

${ }^{11}$ np. kreskowanie samogłoski «a». [Feliński 1840: 137-143].
} 
grał się ów spór, o którym przypomina Turski, bowiem po publikacji pierwszego tomu dzieł autora Barbary Radziwiłłówny krytyczny głos w sprawie sformułowanych tam zaleceń w zakresie ortografii wypowiedział właśnie znany matematyk (Do Redaktora «Pamiętnika Warszawskiego», z Kruszwicy 21. października roku 1816) [Szczeropolski 1816: 487-504]. Mylił się zatem Feliński, gdy myślał, że zasłużeni w literaturze krajowej i poważani przez niego mężowie najłatwiej mu przebaczą niekiedy odmienne od nich myślenie. Najprędzej bowiem zrozumieją, że pobudką jego wystąpienia była troska o mowę ojczystą [Feliński 1840: 106].

W obronie własnych przekonań wystąpił Feliński w pracy pt. Rozmowa w Zaciszy z powodu listu Pana Szczeropolskiego [Feliński 1840: 144-152]. Stanowi ona ostatnią część polemiki nad polską pisownią, w szczególności nad «j», jaka rozegrała się pomiędzy Alojzym Felińskim i Janem Śniadeckim, a o której pisze w wierszu Turski. Wołynianin swoją odpowiedź sformułował kontaminując formę dialogu z elementami palinodii i domieszką asteizmu. Tym samym w humorystyczny sposób, przy użyciu ironii («Dobrą jest ironia na krnąbrne narowy») [Turski 1825: 58], zmierzył się z zarzutami autorytetu znad Gopła ${ }^{12}$ («krytyka przy jeziorze Gople, / Sączy na Felińskiego cierpkie nieco krople») [Turski 1825: 58]. Feliński - formułując swą odpowiedź w sposób ironiczny - sięgnął po nowe (odmienne niż w Przyczynach ...) środki perswazji, a dzięki temu znaczenie własnych propozycji ortograficznych jeszcze wyraźniej uwypuklił. Przywoływane w Rozmowie... zarzuty były wymierzone tak naprawdę w Szczeropolskiego (i są jego pretensjami uprzednio kierowanymi do autora Barbary...). Feliński za sprawą swych literackich stronników - głównie Wacława i Proboszcza, błędne myślenie Szczeropolskiego wyraźnie wyeksponował i ośmieszył13.

Ostatecznie Feliński z tego sporu wychodzi obronną ręką, bowiem już wkrótce z pozycji autorytetu wypowiedzieli się na temat propozycji ortograficznych rozwiązań, wysuwanych przez autora Przyczyn..., członkowie Towarzystwa Przyjaciół Nauk i uznali, że «korzyści, jakie Feliński upatrzył w użyciu spółgłoski «je», tak są oczywiste [...], iż tylko wzbronny wszelkiemu przekonaniu upór, albo mniej rozważny w zastosowaniu pośpiech, może je podawać w wątpliwość [...] Postać, którą w księgach naszych już nie nową widzimy, bo w Biblii Gdańskiej, [...] z wszelką dokładnością jako spółgłoska jest używana [...] nie może nikogo nowością, a tem mniej dziwactwem odrażać. Trudno zapewne zmieniać dawne nawyknienia; trudniej przekonywać tych, co jakiejkolwiek używają pisowni, pewni, że zrozumianymi będą, wszelką poprawę za obojętną poczytują» [Rozprawy i wnioski o ortografii 1830: 161-162]. Dodajmy, że ortograficzna zasada zaproponowana przez Felińskiego przyjęła się i przetrwała do czasów współczesnych.

Na uwagę zasługuje fakt, że Turski - przypominając reformatorskie na polu językoznawczym dokonania Felińskiego - nie tylko zwraca uwagę na znaczenie zawodowej działalności dramaturga, ale również pośrednio opisuje osobowość autora Barbary... oraz znamienne dla niego cechy charakteru:

Tam krytyka ujęta łagodności zdaniem,

\footnotetext{
${ }^{12}$ Już na samym początku użyta przez niego peryfraza «mieszkaniec znad Gopła» z jednej strony maskuje prawdziwe nazwisko Śniadeckiego, z drugiej zaś jednoznacznie do niego się odnosi [Feliński 1817: 383].

${ }_{13}$ Przypomnijmy niektóre z nich: nazwanie Warszawy «siedliskiem odszczepieńców języka» [Feliński 1817: 383] czy uwagi wypowiadane przez Sąsiada (Wawrzyńca Rozsądnickiego), stronnika Szczeropolskiego: obrzydły z oporu i niechlujstwa literackiego pedantyzm, wykrętarstwo gramatyczne, karbowani i ospowaci pisownicy, gdański bękart [Feliński 1817: 383]. Zob. też uwagi sformułowane przez Jana Sniadeckiego [np. Szczeropolski 1816: 501].
} 
Już nie jest gorzkiej żółci, lecz serca wylaniem.

Uniesionych spórników w nektar zmienia jady,

Kto idzie w piękne wieszcza Wołyńskiego ślady.

Mniemań różność bynajmniej z Kopczyńskim nie draźni,

Ciągiem życia obydwóch wytrwałej przyjaźni [Turski 1825: 58].

Jak podkreśla Klemens Kantecki, porywczość nie leżała w naturze Felińskiego, odznaczał się on bowiem serdecznością i dobrodusznością, jednak «doznawszy zawodu okazywał się nieugiętym i ze szlachetnym oburzeniem odwracał się na zawsze od tego, co nadużył jego ufności» [Kantecki 1879: 75].

Jako uprzejmego, rozsądnego i niekonfliktowego człowieka zapamiętała dramaturga także jego bratowa - Ewa Felińska, która wspominała:

Ruchy miał prędkie, fizjonomią bardzo ożywioną, wyraz jej zmieniał się co chwila przechodząc w rozmaite tony, jednak uprzejmość była głownym charakterem: a czy przebiegła po twarzy chmurka smutku, czy się rozpromieniła wesołością, czy zadumanie wysyłało gdzie myśl daleko, to chwilowe wrażenie znikało w mgnieniu oka i znów na twarzy osiadała pogoda i uprzejmość» [Felińska 1858: 200]. [Dalej zaś zauważa - M.P.K.]: Alojzy miał humor miły, wiadomości wielostronne, serce dobre, sposób myślenia szlachetny i prawy, pogląd na rzeczy zdrowy, wolny od wszelkiej przesady. Nie miał on tego orlego polotu myśli, która cechuje geniusze, co wzbiwszy się na wysokość niedostępną dla innych obszernym rzutem oka objąwszy rozprysłe części, skupia je w swej potężnej źrenicy, a pojąwszy całość, i wzajemny stosunek części, umie jednem silnem nakreśleniem skreślić tę całość i wytłumaczyć ją innym [Felińska 1858: 208].

Poza łagodnością i uprzejmością Turski wskazuje także na przyjacielskie więzy łączące Felińskiego z ludźmi ówczesnej Warszawy ${ }^{14}$, wskazując przy tym na Onufrego Kopczyńskiego. Należy podkreślić, że Wołynianin osobiście zetknął się z twórcą narodowej gramatyki, początkowo w Warszawie, w salonie marszałka sejmu, Stanisława Małachowskiego, następnie po powstaniu kościuszkowskim w Dzikowie, majątku Tarnowskich [Zob. Ratajczakowa 1996: 175]. Autor wiersza Do cieniów ... wyraźnie podkreśla działalność dramaturga związaną z płaszczyzną społecznozawodową (relacje z ludźmi, twórcze zatrudnienia czy charakter i sposób prezentacji własnych poglądów). Tym samym wprowadza do swojego utworu informacje wartościujące, które w przedstawieniu Alojzego Felińskiego pełnią pośrednio funkcje waloryzujące (podkreślenie wartości prac artysty, pozytywne cechy usposobienia czy przyjazne relacje z innymi ludźmi - przyjacielska znajomość z Kopczyńskim przydaje osobie Felińskiego oraz jego poglądom dodatkowego splendoru).

Ponadto obaj twórcy poetyckich wspomnień przywołują główny tytuł do sławy dramaturga - Barbarę Radziwitłównę (1811 r.):

Gdzie mężów zacnych wiążą uczucia szlachetne,

Gdzie miłość oświecenia ciemnotę rozprasza,

Tam Melpomena wieńce i nagrody świetne,

Najgodniejszej ofierze czcicielów ogłasza.

Pogłos się w jego ustroniu przedziera,

Ożywia umysł i serce, i usta,

\footnotetext{
${ }^{14}$ Szerzej na ten temat piszą np. [Hoffmanowa z Tańskich 1875: 382-392] oraz [Bar 1948: 408-410].
} 
Stałością duszę uzbraja Augusta,

Przebywa Wisłę i wieniec odbiera [Szadbey 1820].

Piękne jego talenta duch skromności krasił,

Zapał zwalczenia mniemań, drugich zdaniem gasił.

Upadną pomylenia, trafność zostanie się,

I twą Feliński! pracę w późny czas uniesie.

Twa Barbara czułością zwycięża rywalkę,

Jej wyższość mniej wątpliwą rozstrzygnęła walkę [Turski 1825: 58].

Obaj poeci przypominają o triumfie tragedii, którą Feliński bez końca poprawiał, a znawców i przyjaciół prosił o opinie i korekty. W następujący sposób o sukcesie dramatu ${ }^{15}$ wypowiedziała się Dobrochna Ratajczakowa:

Warszawa jest olśniona. Barbara zaczyna własne życie, przepisywana bez końca. Zstępuje z literackiego parnasu i wysokich salonów coraz niżej. Szymon Konopacki, sekretarz tarnowskiego i protegowany Felińskiego, który przepisywał poecie tragedię, zaprasza na jej odczytanie swoich kolegów. Zachwyceni słuchacze wydzierają z rąk kopisty bezcenny autograf i rozszarpują go na części, «aby je zatrzymać przy sobie jakoby świętą relikwię» [Ratajczakowa 1996: 182].

Turski dodatkowo (poza informacją o wadze dramatu) podkreśla skromność jej autora w obliczu tak wielkiego sukcesu, z jakim się wówczas spotkał, a także wspomina o uwagach krytycznych, które wokół tragedii wypowiadano ${ }^{16}$ (te bowiem także towarzyszyły dziełu, mimo że prowadzono je mniej zapalczywie niż w przypadku Przyczyn...).

Autorzy wspomnień podkreślają także, że tytuł do sławy przysporzył Felińskiemu przekład Ziemianina, czyli ziemiaństwa francuskiego Jacques’a Delille’a (1816 r.):

Siada... i talent Delila szczęśliwy,

W języku polskim każdego zachwyca [Szadbey 1820: 185].

Jeżeli mego zdania nic tu nie omyla,

Widzę w twym Ziemianinie naszego Delila [Turski 1825: 58].

Wiele lat później Adam Bar podkreślał, że «tłumaczenie dokonane zostało pięknym językiem; nikt przed Felińskim, a po nim dopiero Mickiewicz, nie umiał z taką plastyką odtworzyć obrazów przyrody [Bar 1948: 409]. Poeta zdobył się na przekład, co wyjaśniał podczas posiedzenia Warszawskiego Towarzystwa Przyjaciół Nauk $^{17}$, ponieważ poemat Delille’a idealnie przylegał «do obrazu Polski widzianej przez pryzmat prowincji jako przestrzeń rolniczo-sąsiedzka, określona przez szlachecki stan posiadania, wreszcie przekonanie, że każda nasza wioska ma szansę stać się kampania felix» [Ratajczakowa 1996: 179].

\footnotetext{
${ }^{15}$ Sukces Barbary Radziwiłlówny odbił się w Warszawie szerokim echem i otworzył Felińskiemu drzwi do najbardziej znamienitych wówczas salonów [Zob. Kantecki 1879: 100-113].

${ }^{16}$ Zob. na ten temat np. uwagi Mariana Szyjkowskiego [Szyjkowski 1950: 20-21].

17 Tekst przemówienia poety został opublikowany w «Gazecie Warszawskiej» [Feliński 1809: 1531].
} 
Należy także podkreślić, że Wincenty Turski dołącza jeszcze do szeregu znaczących prac Felińskiego pamięć o przekładzie Wirginii Vittoria Alfieriego $\left(1815 \mathrm{r.}^{18}\right)$ [Turski 1825: 57].

W przytoczonych powyżej fragmentach, pochodzących z wierszy Szadbeya i Turskiego, obserwujemy obecność szablonów, które występują w prasowych sylwetkach-wspomnieniach (np. nazwisko, określenia charakteryzujące osobę ze względu na zawód, epitety waloryzujące) [Por. Wojtak 2004: 124]. Należy podkreślić, że informacje dotyczące dorobku literackiego autora Barbary ... pozwalały poetom zaprezentować Felińskiego jako specjalistę w dziedzinie, w której rozwijał się na polu zawodowym. Istotne jest, że wspominają oni twórczość Wołynianina, nadając jej przekrojowy charakter (zwracają uwagę na przekłady, oryginalne próby dramatyczne czy reformatorską działalność kodyfikatora języka). Tym samym czytelnik wierszy Szadbeya i Turskiego otrzymywał wizerunek wspominanego artysty jako osoby twórczej i kreatywnej.

Autor wiersza Do cieniów... zawodową działalność Felińskiego wzbogaca o informacje biograficzne związane z prywatną sferą życia artysty. Pisze bowiem:

Mamże ku Wołyniowi zwrócić moją mowę?

Chcąc uczcić Felińskiego drugą czci połowę?

Już Ciebie zadość wielbi Graffa Olizara,

We wszelkim swoim względzie szlachetna ofiara.

Felińska? twych zaszczytów nie będę tu głosić,

Nad pochwałę i losy umiesz siebie wznosić.

Dość było Felińskiego zostać lubą żoną:

By Matkę płodów zacnych z uczczeniem wielbiono [Turski 1825: 60].

Przypomnijmy, że Ewa Felińska, wspominając Alojzową, pisała o niej jako o kobiecie prostej, dobrej, łagodnej, «bez żadnych pretensyj, całe życie przepędziłyśmy z nią w najściślejszej przyjaźni bez żadnej chmurki» [Felińska 1858: 204], jednak (jak sama zaznacza) zyskiwała ona dopiero przy bliższym poznaniu, pierwsze wrażenie mogło budzić mieszane uczucia [Felińska 1858: 203]. Turski bliżej nie charakteryzuje Józefy Omiecińskiej - za zaszczyt dla niej uznaje małżeństwo z autorem Barbary... oraz posiadanie przez nich wspólnego potomstwa. Można zatem stwierdzić, że z jednej strony autor wiersza Do cieniów... przywołuje Felińską, aby w ten sposób dopełnić obraz dramaturga o portret człowieka, który potrafił założyć kochającą i szanującą się rodzinę. $Z$ drugiej zaś Turski zgrabnie mógł przejść do zakończenia, w którym zestawił małżonkę poety z postacią Gustawa Olizara, marszałka guberni kijowskiej, który

zaopiekował się majątkiem i rękopisami, tymi «drogimi skarbami ojczyzny» jako «Polak, Wołynianin i uczeń Czackiego», odpowiadając w ten sposób na wyrażone przed laty obawy autora: «wszystko mrze wkoło mnie, co ze mną żyło; kto wie... Edycja pośmiertna! Zajmie się moimi szpargałami kto? i jak? Wreszcie cóż mi z tego? nawet moim dzieciom? (do Rudzkiego, 19 kwietnia 1815) [Ratajczakowa 1996: 185].

Ten uczeń krzemienieckiego Liceum wraz z Józefą Felińską przygotował zbiorowe wydanie dzieł autora Barbary Radziwiltówny. [Feliński 1816-1821: t. 2]. W ten sposób spadkobiercy spuścizny po Felińskim wznieśli mu pomnik «trwalszy od spiżu» i granitu. Warto przypomnieć, że na wagę pracy Felińskiej i Olizara zwracał uwagę także przyjaciel poety, Michał Wyszkowski, który mówił:

\footnotetext{
${ }^{18}$ Zob. na ten temat uwagi Adama Bara [Bar 1948: 410].
} 
Gorliwi wielbiciele Felińskiego, skojarzeni chwalebnym związkiem w tym celu, aby unieśmiertelnić imię jego, przedsiębiorą wydać najrychlej na widok publiczny pozostałe rękopisma, które miały drugi tom pism jego zapełniać, a następnie, ozdobnem wydaniem dzieł wszystkich, przy dokładnym opisie życia i czynów Autora, księgozbiór Polski zbogacić [Wyszkowski 1821: 125].

Dar marszałka i małżonki poety zapewniał trwałość nazwiska Felińskiego ${ }^{19}$, jego sławy, dlatego - z jednej strony autorzy sylwetek-wspomnień po raz kolejny wyrażają żal spowodowany utratą artysty:

Serce ulega pod żalu uciskiem,

$\mathrm{O}$ ! losie wszystko będzie twym igrzyskiem?

Wszystkoż dla cię okrutny, swoje prawa traci?

Niczemże są stracone przyszłości nadzieje;

Żal Ojczyzny, rodaków, przyjaciół i braci?

Dla twegoż urojenia dziś każdy łzy leje? [Szadbey 1820: 185]

Znosimy Alojzy! cios zgubny za ciosem:

Kiedyż bydź poprzestanie los nasz srogim losem?

Uczucia z żalów serca wydobyte głębi,

Co ich nawet lat późnych zamróz nie oziębi [Turski 1825: 60].

Z drugiej zaś mają nadzieję na wieczną obecność Felińskiego pośród swojego narodu, właśnie za sprawą jego dzieł, które nie ulegają zniszczeniu i wciąż stanowią przekaźnik myśli i słów ich autora:

Ale nie: stałość osuszy powieki,

Niech ciało słabe, niszczy twa potęga,

Kto sławą świetną wieczności dosięga,

Ten uszedł losu, ten żyje na wieki [Szadbey 1820: 185].

A Męża jeniuszu relikwijne szczątki,

Uwiecznią dla nas drogie was dwojga pamiątki.

Przyjmcie tu w należytej wartości ich cenie,

Jak mój hołd Wam oddany Felińskiego cienie,

Duch to wasz smutne życia rozwesela chwile,

I mimo nudów wieku dni me spędza mile [Turski 1825: 60, 61].

Tym samym finalna część poetyckich wspomnień to swoistego rodzaju konsolacja. Poeci pisząc o odejściu Felińskiego uzmysławiaja co prawda znikomość i skończoność ludzkiego losu, ale jednocześnie uświadamiaja czytelnikom swoich tekstów, że twórczość dramaturga zapewnia mu pamięć kolejnych pokoleń. W ten sposób niejako przeciwstawiają fizycznemu umieraniu nieśmiertelność i sławę osiągniętą przez zmarłego za sprawą pozostawionej po nim spuścizny. Można zatem sądzić, że zamieszczane w prasie sylwetki-wspomnienia to nie tylko przypomnienie działalności

${ }^{19} \mathrm{O}$ wspólnej pracy Olizara i Felińskiej nad zebraniem i wydaniem spuścizny po autorze Barbary... pisze między innymi Wojciech Piotrowski [Piotrowski 2004: 335-336 oraz Piotrowski 2005: 159]. 
Alojzego Felińskiego na płaszczyźnie literatury, ale próba stwierdzenia, że za sprawą swych dzieł już na zawsze zostanie on niejako wpisany w istnienie społeczności.

Podsumowując można stwierdzić, że dziewiętnastowieczne wiersze będące poetyckim wyrażeniem żalu po zmarłym Felińskim przede wszystkim stanowiły wspomnienie artystycznej działalności dramaturga, ponadto zawierały elementy wartościujące oraz informujące o przymiotach charakteru krzemienieckiego profesora i jego zasługach literackich czy reformatorskich. Z uwagi na fakt, że drukowano je w prasie, mogły one w znacznej mierze spełniać funkcję gatunku, który dziś określa się mianem sylwetki-wspomnienia, bowiem charakteryzowały osobowość i wybrane wycinki z życia opisywanego artysty, a zatem ich struktura jest w pewnym stopniu spetryfikowana (powiadomienie o śmierci Felińskiego, uwypuklenie zasług poety i tym samym oddanie mu szacunku, w końcu próba jego upamiętnienia). Odejście od mowy niewiązanej można traktować jako wyróżnik prezentowanych wspomnień wynikający z dbałości o atrakcyjność przekazu i - jak podkreśla Maria Wojtak szczególnie praktykowane jest to w sytuacjach, gdy wspomnienie dotyczy osoby, która uprawiała poezję [Por. Wojtak 2004: 127, 129]. Ponadto badaczka podkreśla, że «sylwetka» może przybierać różnorodne kształty, a istotny jest jej wymiar pragmatyczny - przedstawienie i pochwała określonej osoby oraz aspekt poznawczy - charakterystyka prezentowanego człowieka. Należy przy tym respektować pakt faktograficzny, co jednak nie oznacza unikania różnych form wartościowania czy stylistycznego zdobnictwa [Por. Wojtak 2004: 121]. Wiersze Szadbeya i Turskiego z pewnością mogą pełnić funkcję prasowych sylwetek-wspomnień.

\section{СПИСОК ВИКОРИСТАНОЇ ЛІТЕРАТУРИ}

1. Aleksandrowska E. z zespołem (oprac.), 1966, Bibliografia Literatury Polskiej «Nowy Korbut», t. 4: Oświecenie, A-H, Warszawa, s. 451-456, [hasło: Feliński Alojzy].

2. Aleksandrowska E. z zespołem, red., 1970, Bibliografia literatury polskiej «Nowy Korbut», t. 6*: Oświecenie, $P-\dot{Z}$, Warszawa, s. 375-377 [hasło: Turski Wincenty].

3. Bar A., 1948, Feliński Alojzy, [w:] Polski Stownik Biograficzny, pod red. W. Konopczyńskiego, t. 6: Dunin Rodryg-Firlej Henryk, Kraków, s. 408-410.

4. Danielewicz J., 1984, Wstęp do: Liryka starożytnej Grecji, wyd. 2, oprac. J. Danielewicz, BN II, nr 90.

5. Felińska E., 1858, Pamiętniki z życia, t. 1, seria 2, nakładem i drukiem J. Zawadzkiego, Wilno.

6. Feliński A., 1816-1821, Pisma własne i przekładania wierszem, t. 2, Warszawa.

7. Feliński A., 1840, Przyczyny używanej przeze mnie pisowni, w: tegoż, Dzieła. Wydanie nowe, t.1, Wrocław, s. 103-191.

8. Feliński A., 1817, Rozmowa w Zaciszy z powodu listu Pana Szczeropolskiego, «Pamiętnik Warszawski, czyli Dziennik Nauk i Umiejętności», t. 7, s. 381-398.

9. Feliński A., 1809, Tekst przemówienia poety wygłoszony podczas Sesji Towarzystwa Królewsko-Warszawskiego dn. 18 września (ukończenie), «Gazeta Warszawska», nr 83, s. 1531.

10. Guzek A. K., 2004, Krzemienieckie pót roku Alojzego Felińskiego, [w:] Krzemieniec. Ateny Juliusza Stowackiego, pod red. S. Makowskiego, Warszawa, s. 200-211.

11. Hoffmanowa z Tańskich K., 1875, Alojzy Feliński, [w:] tejże, Dzieła, t. 6, pod red. N. Żmichowskiej, Warszawa, s. 382-415.

12. Jodłowski S., 1979, Losy polskiej ortografii, Warszawa, s. 13-162.

13. Kantecki K. P., 1879, Dwaj krzemieńczanie, cz. 1: Alojzy Feliński, Lwów, s. 1-157. 
14. Kopaliński W., Stownik symboli, wyd. 2, Warszawa 1991, s. 46-48, hasło: cień.

15. Kopczyński O., 1778, Gramatyka dla szkół narodowych, Warszawa, s. 1-104.

16. Linde S. B., Stownik języka polskiego, 1808, t. 1, cz. 2: G-L, Warszawa, s. 810, hasło: gwicht.

17. Linde S. B., Stownik języka polskiego, 1811, t. 2, cz. 2: P, Warszawa, s. 929; 1038, hasła: portret; probierny, probny, probierski.

18. Linde S. B., Stownik języka polskiego, 1814, t. oznaczony jako 6: $U-Z$, Warszawa, s. 328-329, hasło: wspominacz.

19. Łoś J. N., 1917, Pisownia polska w przeszłości i obecnie, Kraków, s. 7-222.

20. Molski M., 1821, Wiersz na zgon ś.p. Stanistawa Hrabi Potockiego, wojewody, prezesa senatu królestwa polskiego, w dniu 14 miesiaca września 1821 zmartego, «Dziennik Wileński», t. 3, nr 1, s. 313-315.

21. Patro-Kucab M., 2014, Ciag dalszy sporu o «intruza gdańskiego», czyli Alojzy Feliński ripostuje Janowi Śniadeckiemu («Rozmowa w Zaciszy z powodu listu Pana Szczeropolskiego»), [w:] Kultura mówienia dawniej i dziś, pod red. M. Kułakowskiej i A. Myszki, Rzeszów, s. 101-111.

22. Patro-Kuсаb M., 2013, Риторичність похоронних промов і посмертних спогадів (на прикладі панегіриків, присвячених Алоізію Фелінському [Retoryczność mów pogrzebowych $i$ wspomnień pośmiertnych (na przykładzie oracji poświęconych Alojzemu Felińskiemu)], «Styl i tekst», pod red. N. Szumarowej, wypusk 14, Kijów, s. $119-128$.

23. Piotrowski W., 2004, Gustaw Olizar (1798-1865) [w:] Krzemieniec. Ateny Juliusza Stowackiego, pod red. S. Makowskiego, Warszawa, s. 334-344.

24. Piotrowski W., 2005, Życie umystowe Krzemieńca 1805-1832, Piotrków Trybunalski.

25. Ratajczakowa D., 1996, Alojzy Feliński (1771-1820), [w:] Pisarze polskiego Oświecenia, pod red. T. Kostkiewiczowej i Z. Golińskiego, t. 3, Warszawa, s. 173-198.

26. Rozprawy $i$ wnioski o ortografii polskiej przez Deputacja od Królewskiego Towarzystwa Warszawskiego Przyjaciót Nauk wyznaczona, 1830, Warszawa, s. $161-162$.

27. Sowiński J., Mowa Jana Sowińskiego po wprowadzeniu do kościoła Licealnego zwłok śp. Alojzego Felińskiego, miana dnia 15. Lutego 1820 r. w Krzemieńcu, 1820, «Pszczoła Polska», t. 1, s. 329-334.

28. Szadbey G. I., 1820, Elegia na śmierć Alojzego Felińskiego, «Rozmaitości», dodatek «Gazety Lwowskiej», nr 47, s. 185.

29. Szczeropolski Z. [Sniadecki Jan - nazw.] 1816, Do Redaktora «Pamiętnika Warszawskiego», «Pamiętnik Warszawski, czyli Dziennik Nauk i Umiejętności», t. 6, s. 487-504

30. Szyjkowski M., 1950, Wstęp do: A. Feliński, Barbara Radziwitłówna, tragedia w pięciu aktach, wyd. 6, wstępem i objaśnieniami opatrzył M. Szyjkowski, Wrocław, s. 3-24. BN I, nr 9.

31. Turski W., 1825, Do cieniów Alojzego Felińskiego, «Weteran Poznański», nr 1, s. $57-61$.

32. Wojtak M., 2004, Gatunki prasowe, Lublin, s. 120-130.

33. Zięba A., Biogram Grzegorza Ignacego Szadbeya, [w:] Portrety polskich Ormian, 2014, kalendarz wydany przez Fundację Kultury i Dziedzictwa Ormian Polskich na 2014 rok, nakładem Fundacji Kultury i Dziedzictwa Ormian Polskich, oprac. M. Agopsowicz, projekt graficzny E. Łysakowska, przygotowanie ilustracji do druku M. Sutryk, red. tekstów Z. Jurkowlaniec, tłum. biogramów na język ormiański E. Broyan i S. Nersisjan, tłumaczenie na język ormiański informacji o Fundacji: Piruza Mnacakanian, Warszawa. 


\title{
POETIC PROFILE-MEMOIRS COMMEMORATING THE LITERARY ACTIVITY OF ALOJZY FELIŃSKI (BASED ON THE POEMS PUBLISHED IN THE $19^{\mathrm{TH}}$ CENTURY PRESS)
}

\author{
Dr. Magdalena Patro-Kucab \\ Institute of Polish Philology of Univesty of Rzeszow \\ Rejtana avenue, 16c, 35-959 Rzeszów, Poland \\ e-mail:mpatro@ur.edu.pl
}

The article presents the authoress' analysis and interpretation of the works of Grzegorz Ignacy Szadbey entitled Elegia na śmierć Alojzego Felińskiego (Elegy for the death of Alojzy Feliński), published on 25 April 1820 in «Rozmaitości» (the supplement to "Gazeta Lwowska») and Wincenty Turski - Do cieniów Alojzego Felińskiego (To the shadows of Alojzy Feliński), published in «Weteran Poznański» in February 1825.

The interpretation is not only aimed at presenting the portrait of Feliński, which was created by the poets indicated above, but above all it is an attempt to present the aforementioned poems in the press convention of a profile-memoir.

The authoress wishes to prove that Szadbey and Turski's poems are of informative nature on one hand (they bring knowledge regarding Feliński's occupational activity), but they also contain evaluation elements - they present the author of Barbara Radziwiłłówna as an excellent poet and a noble human being.

Key words: profile-memories and portraits of Alojzy Feliński, press, newspaper text, noble model.

\section{POETYCKIE SYLWETKI-WSPOMNIENIA UPAMIETNIAJĄCE LITERACKA DZIALALNOŚĆ ALOJZEGO FELINSKIEGO (NA PRZYKŁADZIE WIERSZY ZAMIESZCZONYCH W DZIEWIĘTNASTOWIECZNEJ PRASIE)}

\author{
Dr. Magdalena Patro-Kucab \\ Instytut Filologii Polskiej, Uniwersytet Rzeszowski \\ aleja Rejtana 16c, 35-959 Rzeszów, Polska \\ e-mail:mpatro@ur.edu.pl
}

W artykule autor analizuje i interpretuje dzieła Grzegorza Ignacego Shadbeya «Elegia na śmierć Alojzego Felińskiego» który został opublikowany 25 kwietnia $1820 \mathrm{w}$ «Rozmaitościach» (dodatek do «Gazety Lwowskiej») i Vincenta Toursa - Do cieniów Alojzego Felinskiego, opublikowanym w «Weteranie Poznańskim» w lutym 1825 roku. Jedynym celem tej interpretacji nie jest ukazanie portretu Felinskiego, który został zawarty u poety, o którym wspomniano powyżej, ale przede wszystkim próba przedstawienia powyższych wersetów drukowanych w pamiętnikach konwencyjnych. Autor chce pokazać, że poezja Shadbeya i Turskego ma charakter informacyjny. $Z$ jednej strony przynoszi wiedzę o działalności zawodowej Felinskoho, z drugiej zaś zawiera elementy oceny - czyli autorka Barbara Radzyvylivny, świetna poetka i szlachetny człowiek.

Key words: pamiętniki i portrety Aloziya Felinskoho, prasy, wiadomości tekstowe, szlachetny wzór. 